\title{
Ben Jervis \\ Resilience and Society in Medieval \\ Southampton: An Archaeological Approach to Anticipatory Action, Politics, and Economy
}

\begin{abstract}
Resilience is a key theme in contemporary urban studies, with researchers seeking to understand what it is that makes some urban communities better equipped to cope with trauma than others. However, this scholarship rarely draws on historical examples to understand how resilience might emerge over the long term. This chapter introduces key concepts relating to resilience and the ways in which communities are able to anticipate trauma and applies these ideas to understanding the resilience of the community of medieval Southampton. Southampton faced a number of traumatic events in the fourteenth and fifteenth centuries, not least the Black Death and a French raid in 1338. Evidence from archaeological excavations in the city is drawn upon to consider the different ways that members of Southampton's community were able to protect their interests, build resilience and anticipate trauma, and the implications of their actions for urban development. The chapter demonstrates how the idea of resilience can be used to provide deeper insights into the political structure of medieval towns, and also assesses how archaeological evidence might be used to further develop and test concepts which are more typically used in understanding the modern city.
\end{abstract}

Keywords: resilience, anticipation, community, urban, port, medieval, Southampton

Resilience is an important concept across the humanities and social sciences, although its meaning is contested. Developing from origins in the natural sciences, in basic terms resilience is the ability of a system to 'bounce back' from some form of trauma (either caused within the system or from the intervention of some externality), either to its previous state or through adaptation. ${ }^{1}$ The importance of adaptation has been repeatedly stressed, as it is the means through which systems build the capacity to resist similar traumas in the future. ${ }^{2}$ As the concept of resilience has

1 Neil ADGER, Social and Ecological Resilience: Are They Related?, in: Progress in Human Geography 24 (3) (2000), pp. 347-364, here p. 349; Fran NoRRIs / Susan SteVEns / Betty PFEFFERBAUM / Karen WyCHE / Rose Pfefferbaum, Community Resilience as a Metaphor, Theory, Set of Capacities and Strategy for Disaster Readiness, in: American Journal of Community Psychology 41 (2008), pp. 127-150.

2 Kevin Fox Gotham / Richard Campanella, Towards a Research Agenda on Transformative Resilience. Challenges and Opportunities for Post-Trauma Urban Ecosystems, in: Critical Planning, Summer 2010 (2010), pp. 8-23, here p. 12.

Ben Jervis, School of History, Archaeology \& Religion, Cardiff University, John Percival Building, Colum Drive, Cardiff, UK, CF10 3EU, jervisb@cardiff.ac.uk

Ә Open Access. (C) 2020 Ben Jervis, published by De Gruyter. (c) BY-NC-ND This work is licensed under a Creative Commons Attribution-NonCommercial-NoDerivatives 4.0 International License. 
received increasing use in the social sciences, it has been continuously re-defined and re-imagined. As will be discussed below, many approaches seek to develop generalising models and rules for understanding societal resilience, whilst others, such as the geographer Ben Anderson, ${ }^{3}$ see resilience building as a contextual and complex set of processes. The use of an historical case study, where we can trace socio-economic processes and assess their implications, allows a contribution to be made to this debate, by reflecting upon the extent to which general rules appear applicable and exploring theoretical frameworks which might prove useful for understanding resilience today.

In this chapter I draw on contemporary political discourse to explore the relationship between ideas of adaptability and resilience, arguing that these are different but related concepts which emerge through the performance of social relations. ${ }^{4}$ This relationship between social structure, adaptability and resilience is examined through the consideration of the medieval town of Southampton (Figure 1), which, in the fourteenth and fifteenth centuries, suffered from a range of traumatic and disruptive events, including a raid by the French, the disruption of supply lines due to warfare and sheep murrain and the Black Death. My approach is grounded in 'assemblage theory', a means of approaching the past which stresses the historical contingency of social relations and their unpredictable unfolding. Importantly, it is an approach in which we can define the town not as a fixed spatial entity but as a socio-spatial process, of a community of people, things, materials and ideas in flux, which is both affective upon and effected by external processes. ${ }^{5}$

\section{Modelling Resilience: General Rules}

The notion that resilience exists as a set of general rules can be seen as a product of the concept's origins in the natural sciences, where it was used to explore the ways in which ecological systems are able to recover from external trauma. From a socioeconomic perspective, this approach is best exemplified in studies of economic resilience, which seek to develop an understanding of which factors allow an economic system to exhibit resilience, to recover quickly from trauma.

A link between social organisation and adaptability is demonstrated in research within contemporary society. SIMMIE and MARTIN argue that regions pass through an economic cycle of specialisation and, as the economy becomes more specialized, resilience decreases as there is less adaptive capacity; as regions become more

3 Ben Anderson, What Kind of Thing is Resilience?, in: Politics 35(1) (2015), pp. 60-66.

4 Chris ZeBrowsKI, The Nature of Resilience, in: Resilience 1(3) (2013), pp. 159-173, here p. 170.

5 See also Ben JERVIS, Assemblage Urbanism. Becoming Urban in Late Medieval Southampton, in: Archaeological Dialogues 25(2) (2018), pp. 135-160. 


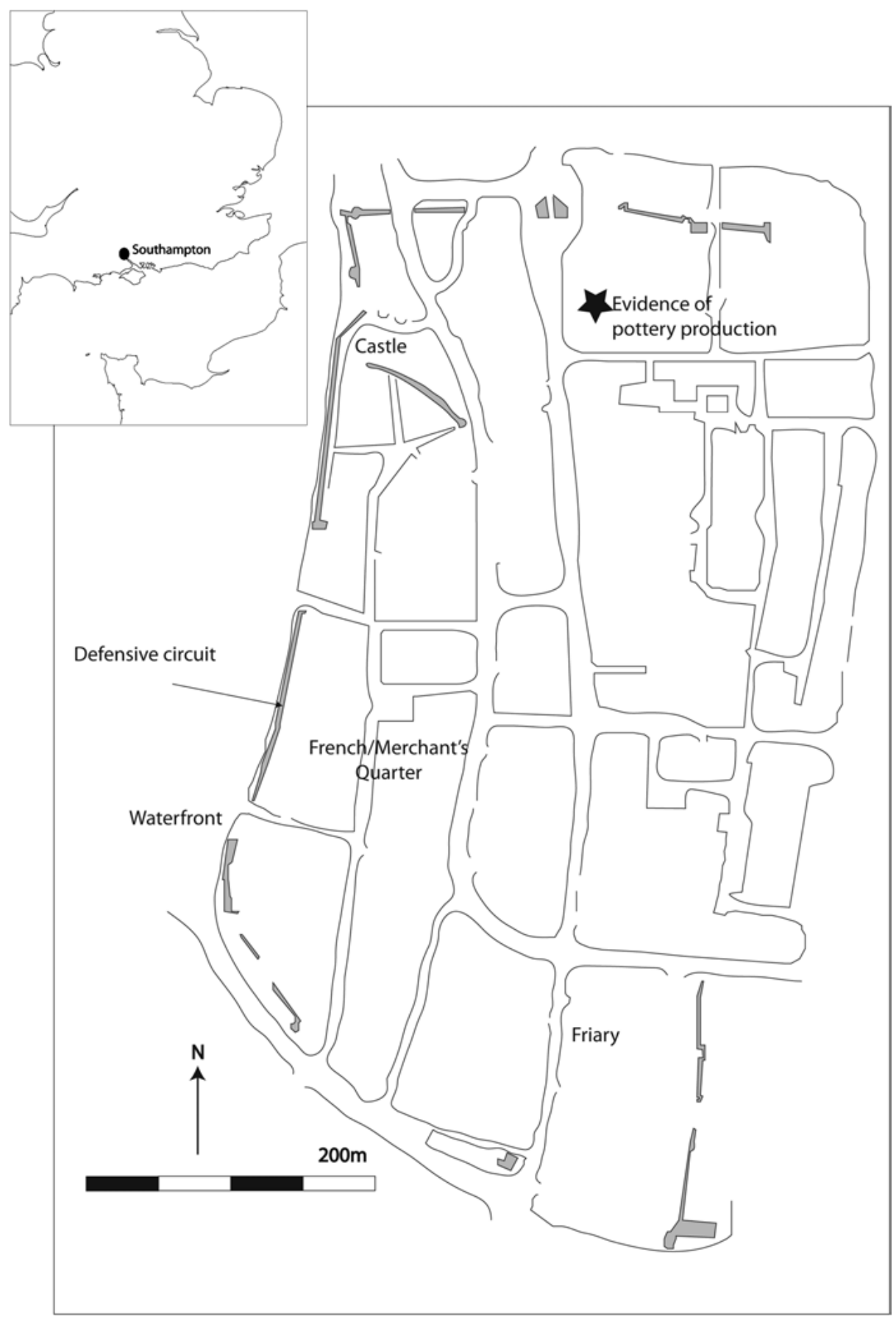

Figure 1: Map of medieval Southampton, showing key locations mentioned in the text. Image: Ben Jervis. 
homogenized in their economic base, they become less resilient. ${ }^{6}$ Generally, more economically, ecologically, or socially diverse systems are considered resilient, as they are more flexible in their ability to adapt to change; however whilst diversity can build resilience through widening access to resources and spreading risk, it might also create conflict and weaken social ties. ${ }^{7}$ Considering the resilience of cities, CHELLERI sees resilience as emerging at the intersection of economic, political, social and environmental networks, proposing that changes in one of these subsystems may have implications for the whole, which can be countered through adaptation. ${ }^{8}$ Thinking about adaptability and resilience therefore requires us to think about towns and cities as networks, with the key to resilience lying in the ability to maintain connections, which might be achieved through diversification of environments or economies, decentralising social and political systems to spread risk, allowing it to return to its basic state whilst at the same time responding to change. ${ }^{9}$

Within this chapter archaeological evidence is used to explore the question of resilience. Similar models based upon systems approaches have long been utilized within archaeology, particularly to explore questions of societal collapse, allowing archaeologists to model general societal pre-conditions for success or failure (although such approaches have not been prevalent within British medieval archaeology), demonstrating the potential for exploring resilience through archaeological data. ${ }^{10} \mathrm{~A}$ similar approach, based on empirical comparison of multiple societies has been developed by CURTIS in an important study of pre-industrial agricultural societies. ${ }^{11}$ Through empirical study he identifies a relationship between the organisation of resources and political strategies and the ability of a community to adapt to crisis. He hypothesizes that communities which are egalitarian are likely to be less vulnerable than those with a more polarized power structure. This resilience may be achieved through adopting

6 James SimmiE / Ron MARTIN, The Economic Resilience of Regions. Towards an Evolutionary Approach, in: Cambridge Journal of Regions, Economy and Society 3 (2010), pp. 27-43; Laura EsTÉVEZMAURIZ / Jimeno FonSECA / Claudiu ForGaCI / Nils BJÖRLInG, The Liveability of Spaces. Performance and/or Resilience? Reflections on the Effects of Spatial Heterogeneity in Transport and Energy Systems and the Implications of Urban Environmental Quality, in: International Journal of Sustainable Built Environment 6(1) (2017), pp. 1-8, online (DOI): http://dx.doi.org/10.1016/j.ijsbe.2016.10.001 (last accessed 15/05/2019).

7 Fox Gotham / Campanella (note 2), p. 14

8 Lorenzo CHELleri, From the "Resilient City" to Urban Resilience. A Review Essay on Understanding and Integrating the Resilience Perspective for Urban Systems, in: Documents d'Anàlisi Geogràfica 58(1) (2012), pp. 287-306.

9 ADGER (note 1).

10 See Patricia McAnANy / Norman YoffEE (eds.), Questioning Collapse. Human Resilience, Ecological Vulnerability, and the Aftermath of Empire, Cambridge 2009; Ronald K. FAULSEIT (ed.), Beyond Collapse. Archaeological Perspectives on Resilience, Revitalisation, and Transformation in Complex Societies, Carbondale 2015, for recent studies and reviews.

11 Daniel CuRTIS, Coping with Crisis. The Resilience and Vulnerability of Pre-Industrial Settlements, Farnham 2014. 
risk-avoidance strategies or repetition of adopting flexible regimes, to adapt to new challenges. In contrast, the coercive or short-termist approaches taken in societies where elites seek to exploit the land for profit is likely to result in vulnerability.

Models of resilience have developed over time with, in particular, a realisation that the ability to adapt is critical, so as not to make a society repeatedly vulnerable to the same trauma; an observation made particularly acutely in studies undertaken in the aftermath of Hurricane Katrina. Such realisations have led to resilience studies developing in new directions, focussing on the adaptive capacity of societies, with particular attention being paid to specific contextual factors rather than general explanatory models. It is within this discourse that the current contribution can be most comfortably situated. It is my contention that any similarities between medieval and modern societies must be proven rather than assumed and, therefore, that the application of general models developed for contemporary society may mask real similarities and differences between the structures of medieval and modern society. Furthermore, their application to medieval evidence may also provide a means to test to the universal applicability of such models, which, in turn, may impact the contexts in which they can be applied today. Whilst much contemporary political discourse around this subject is linked to the way in which a dogma of resilience has developed as a means of protecting the neo-liberal social order of the twentieth and twenty-first centuries, ${ }^{12}$ the basic premise that communities take steps to protect what they believe to be important to their social well-being, and that their paths may be hindered by other interest groups, is one which might be tested through historical or archaeological data, to reveal a range of behaviours which might help us better understand the nature of resilient and sustainable societies. $^{13}$

\subsection{From Systematic Resilience to Adaptation and Anticipation}

In a recent summary of the study of resilience in modern political discourse, ANDERSON has argued that the term is utilized in a variety of different ways, as dogma, power dynamic or policy, for example, with its use intended to have different consequences and arising from different historical processes. ${ }^{14}$ He proposes that rather than homogenising resilience through the development of generalising models, we must embrace this diversity, to understand what kind of a thing

12 Brad Evans / Julian ReID, Dangerously Exposed. The Life and Death of the Resilient Subject, in: Resilience 1(2) (2013), pp. 83-98; Kristina DIPROSE, Resilience is Futile, in: Soundings 58 (2015), pp. 44-56.

13 NoRRIs et al. (note 1), p. 139.

14 ANDERSON (note 3). 
resilience might be in different circumstances, in other words that it is contextually variable. In basic terms resilience is a form of anticipatory action. Whereas adaptability is the capacity of a place to change, resilience implies the use of some strategy to respond to a perceived vulnerability. By exploring these strategies, we can, therefore, seek to understand what was deemed vulnerable and requiring protection by different groups within a society, and the ability that they had to effect some change.

Following ANDERSON a range of different forms of anticipatory action can be taken. ${ }^{15}$ Trauma might be pre-empted, with measures being taken to stop it from ever happening, precautions might be taken to prevent it or limit its effects or communities may accept that an anticipated shock might occur and be prepared for it. If we acknowledge the importance of anticipatory action, we implicitly accept that the futures which unfold are historically contingent, and that certain futures might be formed or prevented through action in different places or times. It may seem obvious that the future emerges from the past, but the critical point is that futures cannot be entirely planned; they emerge in unpredictable ways, which are shaped, in various ways, by patterns of behaviour and natural processes. Resilience therefore becomes a specific utilisation of knowledge; that something is vulnerable and that steps can be taken to make it less so. Threats are emergent; they may arise from social or natural processes, they may have certain implications because of their intersection with other processes. An earthquake is only a threat if these geological processes intersect with the socio-economic processes of everyday life, for example. Resilience therefore implies the identification of something as having value and of a community as having some power to take measures to protect it. ${ }^{16}$

Resilience might be specifically linked to the concept of preparedness, it implies a recognition that something is vulnerable and cannot be entirely protected; rather than prevention it becomes a way of resisting the world, of resisting a possible future. If we perceive of a world unfolding from social relations it might be perceived as a series of potentially dangerous events, which must be anticipated if the social order is to be protected. ${ }^{17} \mathrm{~A}$ difference can, therefore, be identified between the capacity to adapt, which relates to the ways in which a system is structured, and resilience, a socially constructed response to a perceived vulnerability. ${ }^{18} \mathrm{My}$ aim here is to move away from an essentialist position which sees a system as resilient, to explore how vulnerability and resilience emerge from social relations and

15 ID., Preemption, Precaution, Preparedness. Anticipatory Action and Future Geographies, in: Progress in Human Geography 34(6) (2010), pp. 777-798.

16 Ibid., p. 782.

17 Evans / ReID (note 12), p. 83.

18 Gabriella Christmann / Oliver IBERT, Vulnerability and Resilience in Socio-Spatial Perspective. A Social-Scientific Approach, in: Raumforschung und Raumordnung 70(4) (2012), pp. 259-272, here p. 261. 
are processes which might be performed at different scales, with varying and potentially conflicting implications. As SoENS states, "societal resilience and vulnerability of people are clearly two different things"19; whilst infrastructure and institutions may survive this does not mean that communities are not affected by trauma in a variety of ways, which, in some cases, may be due to the restrictions on adaptability caused by those same institutions. Whereas adaptability arises from the nature of the relations which form a social system, resilience emerges from the manipulation of these relations, by moving or distancing elements of it or by taking measures to transform relations. ${ }^{20}$ Therefore, adaptability is imminent within social relations, but resilience is necessarily prior to these relations, as a form of pre-emptive historical action which surfaces in certain performances of the present. ${ }^{21}$ Critically, it is a resistance to the natural adaptability of systems, which might emerge in such a way that it over-writes the existing system; as such resilience is a strategy taken to counter a double threat - of destruction by shock and destruction by unmanaged and unpredictable adaptation. In what follows, I suggest that the archaeological and historical evidence from the Middle Ages offers an opportunity to examine the long-term consequences of anticipatory behaviour, in a way that studies of this behaviour in contemporary societies cannot. Therefore, the aim of this analysis is not to simply test general rules and models but, rather, to reveal the implications of anticipatory behaviour which might allow us to better understand the unintended consequences of resilience building today.

\section{Adaptability, Social Structure and the Middle Ages: An Assemblage Approach}

By focussing on a historical case study, it is possible to use the archaeological context as a laboratory for exploring the implications of these ideas, and of analytical approaches which might help us to better understand the relational character of adaptability and resilience. By understanding a wide variety of ways in which resilience emerges, we become better able to develop strategies to deal with trauma and understand the implications of this behaviour over a period of a century or more, something which is unachievable through a focus on modern situations where decision making processes are ongoing and it is only possible to think about their implications in a hypothetical sense.

19 Tim Soens, Resilient Societies, Vulnerable People: Coping with North Sea Floods Before 1800, in: Past \& Present 241(1) (2018), pp. 143-177, here p. 175.

20 Ibid., p. 167; ESTEVEZ-MAURIZ et al. (note 6), p. 6.

21 Kevin Grove, Agency, Affect, and the Immunological Politics of Disaster Resilience, in: Environment and Planning D: Society and Space 32(2) (2014), pp. 240-256, here p. 245. 
The case study presented here is that of fourteenth- and fifteenth-century Southampton, a major medieval port town in southern England. From an economic perspective, Southampton was remarkably homogeneous. Although there was small scale craft manufacture, with archaeological evidence for iron working and pottery manufacture for example, the economy was principally focussed on trade and servicing merchants. ${ }^{22}$ In the thirteenth century this trade was, itself, particularly homogenous, with wool from Southampton's wider region being the principal export, and wine from Gascony being the principal import. ${ }^{23}$ Generalising models of resilience would, therefore, suggest that Southampton was likely to be highly vulnerable to the political and ecological crises of the fourteenth century, which cut off access to Gascony and impacted the wool yield. ${ }^{24}$

Historical data reveal, however, that Southampton did not fail, but was able to adapt and recover. Although trade was depressed through the middle and later parts of the fourteenth century, Southampton was able to restore its position as an important port in the fifteenth century, largely due to its importance as a landing place for Italian merchants, who exported wool initially to Flanders and later to the Mediterranean, and as a point of entry for exotic goods from eastern trade routes. ${ }^{25}$ The terrier, a survey of property in the town dated to 1454 , but detailing the occupation and ownership of plots over several decades, reveals only a small number of vacant plots despite the devastation of the French raid of 1338, which is reflected in the archaeological record in the form of deposits of burnt demolition debris, and the Black Death in the later fourteenth century. ${ }^{26}$ The population of Southampton likely dropped after the Black Death, although exact figures are not available, limiting the demand for housing, whilst works to the town wall made certain areas which had once been occupied as merchant dwelling less attractive, with them becoming open gardens (potentially widening the biodiversity of the town and increasing food security). ${ }^{27}$ Archaeological evidence demonstrates quick rebuilding in timber rather than stone, including the development of new plots, potentially as speculative rental properties. ${ }^{28}$ Historically, Southampton's burgesses had a high degree of political autonomy, formalized in a charter of 1199. It is clear from their

22 Colin PlatT, Medieval Southampton: The Port and Trading Community, London 1973, pp. 45-46; Duncan BRown, Pottery in Medieval Southampton, c. 1066-1540, York 2002, pp. 128-129.

23 Platt (note 22), pp. 69-77.

24 ADGER (note 1), p. 351

25 Aldwyn RuDDock, Italian Merchants and Shipping in Southampton 1270-1600, Southampton 1951, pp. 151-152.

26 Lawrence Burgess, The Southampton Terrier of 1454, London 1976; Colin PlatT / Richard Coleman-Smith, Excavations in Medieval Southampton 1953-1969, Leicester 1975, p. 37; Richard Brown / Alan HaRdy, Trade and Prosperity, War and Poverty. An Archaeological and Historical Investigation into Southampton's French Quarter, Oxford 2011.

27 Platt / Coleman-Smith (note 26), p. 294.

28 Ibid., pp. 232-246. 
petitions to the crown for relief and the reduction of fee farm, as well as disputes with merchants from other towns that they employed protectionist strategies to sustain a degree of income and limit their burden in times of hardship. ${ }^{29}$ Burgesses held some land outside of the town and were also able to influence their hinterland by providing opportunities for trade and entering into financial arrangements with local producers. ${ }^{30}$ Southampton had a distinct advantage over other local market towns due to the variety of imported goods available, although many of these would only be in the reach of a small number of households in the wider region. We can see, however, in the steps taken by Southampton merchants attempts to secure relations with its wider region and foreign traders, exploiting their position as holding access to the major port for the region.

At a superficial level at least, Southampton seems to have been equipped to absorb the traumas of the fourteenth century, with its trade axis changing towards the Mediterranean, making it an important connection between Italian markets and the southern English cloth industry, both by exporting their products and importing dyestuffs essential for its growth and development. ${ }^{31}$ Rather than seeking to apply general rules to understand how adaptable Southampton was to crisis, my approach here is to explore the nature of resilience and the strategies employed within Southampton and beyond, and to highlight their implications for strategies of resilience today. Within the context of medieval studies, such an approach has further value in re-opening debates over the occurrence of an urban crisis in the later fourteenth and early fifteenth centuries from a new perspective, building on previous conclusions that towns cannot be considered alone but must be examined within their region, an endeavour well suited to the relational approach to adaptability and resilience advocated here. ${ }^{32}$

Recent approaches in urban history, archaeology and geography have sought to move beyond an essentialist approach to the urban, to explore how cities emerge as spatially situated social processes. ${ }^{33}$ Following scholars such as DELEUzE and GuATTARI and DELANDA they see the city as existing as a coagulation of flows, a

29 PlatT (note 22), pp. 119-120.

30 Ibid., p. 253.

31 Michael Hicks, English Inland Trade 1430-1540. Southampton and its Region, Oxford 2015, pp. 154-158.

32 Alan DyER, Decline and Growth in English Towns 1400-1640, Cambridge 1991; Ben JERVIS, Decline or Transformation? Archaeology and the Late Medieval Urban 'Decline' in Southern England, in: The Archaeological Journal 174(1) (2017), pp. 211-243.

33 See, e. g., Dorothy BRANTZ, Assembling the Multitude. Questions about Agency in the Urban Environment, in: Urban History 44(1) (2017), pp. 130-136; Ben JERVIS, Assemblage Theory and Town Foundation in Medieval England, in: Cambridge Archaeological Journal 26(3) (2016), pp. 381-395; Colin MCFARLANE, The City as Assemblage. Dwelling and Urban Space, in: Environment and Planning D: Society and Space 29 (2011), pp. 649-671; Ben JERVIS, Assemblage Thought and Archaeology, Abingdon 2018. 
process of 'territorialisation' in which the city as an entity is formed at the affective intersection of flows of people, goods, resources, materials, ideas and capital, for example. ${ }^{34}$ The city does not exist as such, but occurs as an ongoing process, with the 'mineralisation' of these flows creating the concrete urban landscape as the site of re-occurring social interactions, which necessarily requires it to extend beyond its physical limits. ${ }^{35}$ Urban ecosystems are, therefore, more than the environment of the city itself, but include the wider surroundings, the region which is instigated in the performance of the city. ${ }^{36}$ Such an approach also acknowledges that human agency is not the only form of power within the city. Instead, agency is generated in the coming together of flows, ${ }^{37}$ with the non-human having power to stimulate the emergence of new urban futures or to decay the structures put in place by mechanism of bureaucracy, be that through the decay of materials or the colonisation of open spaces by plant species or the spread of microbial disease. ${ }^{38}$ Whereas adaptability emerges in these different relations, resilience becomes the manipulation of these flows, the management of this potency, to protect specific ways of urban being.

The concept of vibrant materials, particularly drawing on the work of Jane BENNETT, ${ }^{39}$ is increasingly important in archaeological scholarship, and is one with which medieval people might have been sympathetic. Fundamentally this concept requires us to be aware of the power that materials might have over us, meaning that the world is not shaped by human intentionality alone, but by interaction between human and material forces. Medieval examples such as the use of humeral theory in agricultural practices, an approach based in scientific knowledge, and measures taken to prevent the exhaustion of resources such as crop rotation and flood defence measures all demonstrate an ability to manage natural forces. ${ }^{40} \mathrm{We}$ might also see such an appreciation of the power of the material in in the use of apotropaic objects, for example the burial of pilgrim souvenirs to protect a

34 Gilles Deleuze / Felix Guattari, A Thousand Plateaus, London 1987; Manuel DeLandA, A Thousand Years of Nonlinear History, New York 1997.

35 DELANDA (note 34), pp. 26-28; MCFARLANE (note 33), p. 663.

36 DELANDA (note 34), p. 108

37 Astrid van Oyen, Historicising Material Agency. From Relations to Relational Constellations, in: Journal of Archaeological Method and Theory 23(3) (2016), pp. 354-378; BRANTz (note 33).

38 Tim EDEnsor, Vital Urban Materiality and its Multiple Absences. The Building Stone of Central Manchester, in: Cultural Geographies 20(4) (2012), pp. 447-465; Matthew GANDY, Unintentional Landscapes, in: Landscape Research 41(4) (2016), pp. 433-440.

39 Jane BenNETT, Vibrant Matter. A Political Ecology of Things, Durham / NC 2010.

40 Richard Jones / Holly Miller / Naomi SykES, Is it Time for an Elemental (Re)Turn in Archaeology?, in: Archaeological Dialogues 23(2) (2016) pp. 175-192, here p. 183; Rainer SCHREG, Ecological Approaches in Medieval Rural Archaeology, in: European Journal of Archaeology 7(1) (2014), pp. 3-119; Christopher GERRARD / David PETLEY, A Risk Society? Environmental Hazards, Risk and Resilience in Medieval Europe, in: Natural Hazards 69(1) (2013), pp. 1051-1079. 
household or bless the fields. ${ }^{41}$ Rather than focus on these acts as religious, or to simply identify them as 'ritual' behaviour, we can propose that these were anticipatory measures, taken to protect specific ways of life, measures which can also be seen more concretely and explicitly in the endowment of parish churches, religious institutions and chantries. ${ }^{42}$

In his analysis of urban development in medieval Europe, DELANDA identifies two extremes of urban assemblage. ${ }^{43}$ The first is the meshwork, which we might view as a true 'assemblage' of interconnected participants, which come together in unpredictable ways. Within these assemblages past connections open the potential for future ones. Such assemblages occupy a 'smooth' space, in which flows are free to entangle with each other in promiscuous and unpredictable ways, with little control exerted over them. DELANDA suggests that such meshwork assemblages are characteristic of 'gateway' cities, such as ports. These places exist as islands, coagulations of flows from distant places, over which they exert little control. The opposite is the hierarchy, emerging through a homogenising process of stratification. In such cities, components are sorted and bonded together through bureaucratic mechanisms, which can be likened to the sorting and cementing of sediment in the process of rock formation. These might be perceived of as occupying a space which is striated, preventing flows from moving in some directions; 'coding' them to interact in specific ways to lead to futures which, whilst not entirely predictable, are managed. ${ }^{44}$ In both cases futures are historically contingent and unpredictable, but within the hierarchy futures are anticipated and worked upon more explicitly. Such cities may exert control by homogenising the environment around them, either directly or indirectly, becoming central places. Such a theoretical approach finds a degree of historical legitimacy. In his study of economic development in northern Europe in the early medieval period, LOVELUCK contrasts the comparative freedom of coastal areas with inland areas, and sees the growth of ports as an attempt by authorities to exert power over trading activity, whilst acknowledging the need to create urban centres in which merchants had the freedom to accrue capital, receiving protection in return. ${ }^{45}$ From our perspective, adaptability is a characteristic of the meshwork, whilst resilience emerges from stratification, a manipulation of flows to create a homogenized and predictable future, rather than the messy and unpredictable one emerging from an adaptive meshwork.

41 William ANDERson, Blessing the Fields? A Study of Late Medieval Ampullae from England and Wales, in: Medieval Archaeology 54 (2010), pp. 180-203.

42 GeRRARD / PetLey (note 40).

43 DeLanda (note 34), pp. 26-28.

44 Grove (note 21), pp. 247-248.

45 Christopher Loveluck, Northwest Europe in the Early Middle Ages c. AD 600-1150, Cambridge 2013, pp. 302-303. 
In contemporary discussions of the implications of resilience in neoliberal societies it is this stratified element that is emphasized, resilience becoming perceived negatively as a means of maintaining a subjugating status quo. A parallel can be drawn here with the perception of medieval society as rigidly hierarchical. The behaviour of medieval communities was constrained, to varying degrees, by the interests of the elite, although it should be noted that resistance, as exemplified by events such as the peasants' revolt, also constrained elite action. By acknowledging the presence of meshwork elements within medieval society resilience can become something more positive, a means through which communities might overcome some perceived disadvantage, in the medieval context, this might equate to those outside of the seigniorial or urban elite being able to shape their future, providing a counter-narrative to that of subservience, deference, and subjugation. ${ }^{46}$ By exploring the relationship between these different elements of the urban assemblage in historical perspective we can, therefore, potentially contribute alternative ways of looking at the relationships between different forms of power and adaptive capacities in both past and contemporary societies, and view resilience not as a means of power being exerted through a hierarchy, but rather as emerging out of a range of behaviours performed across society.

Meshwork and hierarchy sit on a continuum, the reality being that some cities exhibit more, or less, meshwork elements. Importantly, the dominance of these elements will vary as social relations unfold; hierarchies may become de-stratified as they are 'over-coded' by other processes, perhaps an unanticipated process or one which was insufficiently or ineffectively prepared for, whilst these processes also occur at multiple scales. Cities must constantly change to adapt to threats (through the embracing of meshwork characteristics), but also be stratified to ensure that certain structures are in place to maintain urban society. ${ }^{47}$ Cities are assemblages of assemblages, such as households, themselves heterogeneous bundles of people, things and connections which cause them to 'overflow' the space with which they are associated. ${ }^{48}$ Processes of stratification, of seeking to control the vibrant flows of matter and energy which constitute life, may occur at multiple scales and tension between these scales may also lead to specific processes of anticipation and preparedness emerging at the expense of others. It is these specific processes, and their implications for understanding adaptive behaviour, which are the focus of the remainder of this paper.

46 GROVE (note 21), p. 245.

47 ESTEVEZ-MAURIZ et al. (note 6), p. 5.

48 Michel Callon, Actor-Network Theory - The Market Test, in: John LAw / John HANSARD (eds.), Actor Network Theory and After, Oxford 1999, pp. 181-195. 


\section{Resilience at the Microscale}

DELANDA highlights how medieval towns and cities were microbial laboratories. ${ }^{49}$ Disease could spread quickly, as seen by the rapid spread of plague, with the effect of 'over-coding' existing social structures, breaking down existing structures and creating opportunities for new ones to emerge, as is particularly seen in the changes to the organization of the rural economy in the fifteenth century. ${ }^{50}$ Whilst the understanding of the causes of disease was undeveloped, there was an acceptance of the need for good hygiene to prevent its spread. The capacity to spread disease is a quality of waste matter. Archaeological evidence demonstrates the occurrence of worms, spread through exposure to human excrement and food waste attracted disease carrying rodents for example. ${ }^{51}$ Measures were taken to remove waste from the centre of the town, where limitations on space and the proximity of residents combined to make waste management a key concern. Archaeological excavations reveal extensive excavations of pits in backyards across Southampton. These were dug for a variety of purposes, including as cess pits, and were often back-filled with a range of domestic waste. ${ }^{52}$

By studying the ways in which these pits were filled, the case can be made that processes of vulnerability and resilience building were being played out. A range of analyses demonstrate that waste was not dumped in pits in a haphazard manner, but was structured. Sterile layers, of shell or earth, were deposited. Analysis of fly pupae show that pits were sealed, preventing further insect infestation. ${ }^{53}$ What we are seeing here is an attempt to neutralize the potent elements of this waste matter, to homogenize what had been a diverse mix of objects, food waste and natural substances through a process of stratification; of sorting it into a mulch of waste and cementing its position through burial. ${ }^{54}$ At the micro-level this process was one of managing potential futures, of categorising and disposing of the products of historical processes to prevent them from lingering and playing a role in the future. Rather than relying on an ability to adapt to disease, measures were taken to

49 DELANDA (note 34), p. 110.

50 Bruce CAmpBell, The Great Transition. Climate, Disease and Society in the Late Medieval World, Cambridge 2016.

51 Andrew Jones, Southampton French Quarter 1382 Specialist Report Download E6: Intestinal Parasites, online: https://library.thehumanjourney.net/51/1/SOU_1382_Specialist_report_down load_E6.pdf (last accessed 15/05/2019).

52 Platt / Coleman-Smith (note 26); Brown / HaRdy (note 26), pp. 281-284.

53 David Smiтh, Southampton French Quarter 1382 Specialist Report Download E9: Mineralised and waterlogged fly pupae, and other insects and artropods, online: https://library.thehumanjour ney.net/52/1/SOU_1382_Specialist_report_download_E9.pdf (last accessed 15/05/2019).

54 See also Roos VAN OOSTEN, The Dutch Great Stink: The End of the Cesspit Era in Pre-Industrial Towns of Leiden and Haarlem, in: European Journal of Archaeology 19(4) (2016), pp. 704-727, for a long-term consideration of urban waste management. 
anticipate and prevent its occurrence. Through the repetition of such processes across the town, combined with the enacting of municipal regulations on waste management, ${ }^{55}$ we can see resilience to the threat of disease emerging at the microscale, through individual interactions with waste matter and anticipation of its potential consequences.

Despite these measures, disease was a critical issue in the medieval town. ${ }^{56}$ Humans and microbes co-evolved, humans developing immunity to one strain as new ones developed. It is here that we can bring in to focus the idea that resilience exists as a resistance to the world, as an acknowledgement that risks cannot be entirely removed but that steps can be taken to prepare for and pre-empt them. Disease would always be a risk, but by taking measures to prevent its spread, by acknowledging a source of vulnerability, resilience could be built in some form. What we see in waste management is the removal of vibrant matter from the urban assemblage as a conscious effort to exert some control over an anticipated, but unpredictable future. Importantly this can be characterized as a 'bottom-up' strategy, in which societal power emerges out of multiple performances of anticipatory behaviour distinctive to the urban environment - a widespread enacting of knowledge to manage a future over which the whole community had a stake.

\section{The Politics of Resilience}

Vulnerability to the affect of waste emerged through the processes of urban life. In this case that vulnerability was the result of the proximity and density of people and the redundancy of waste, when, in the countryside, the latter was a valuable source of manure. Resilience and vulnerability are therefore negotiated through and emerge from relations with a human and nonhuman urban world, through which the process of urban assemblage both takes shape in the present and produces relations which shape the future. ${ }^{57} \mathrm{~A}$ focus on a more specific instance of vulnerability and resilience reveals further how the priorities of stakeholders within the town might cause resilience to emerge as a point of tension and rupture between scales of power.

The process of resilience can reveal dynamics of power and serve to re-enforce inequalities. The anticipation of attack caused significant tension between the crown and Southampton's burgess community. Potential weaknesses in Southampton's defences were highlighted in 1321 when a fleet from Winchelsea landed and burnt two

55 Paul StUder (ed.), The Oak Book of Southampton of c. A. D. 1300, Southampton 1910.

56 Carole RAwCLIfFE, Urban Bodies. Communal Health in Late Medieval English Towns and Cities, Woodbridge 2013.

57 ZEBROWSKI (note 4), p. 161. 
ships. The seaward defences of Southampton consisted of an earthen rampart and palisade. Whilst it is unclear as to what extent the defences had been built in stone by the French raid of 1338, the town clearly had defensive weaknesses. The context of the raid was ongoing war with France, and the vulnerability of Southampton as a target either for raids or as a landing place was clearly recognized by the crown. Works were undertaken to the castle in the first decade of the fourteenth century and in 1326 a grant was made of a new toll to fund the town wall. In 1337 a string of warning beacons was erected along the south coast and for the decades after the raid periodic surveys of the defences were required. ${ }^{58}$ The raid of 1338 exposed a vulnerability which had been identified by the crown, who had taken measures to enable the strengthening of the defences of the town. This anticipatory action may never have prevented an attack, but could have mitigated its impact. As it was, the raiding party experienced little resistance, the gates had been barred but were easily broken through. The crown's inability to strengthen the defences came from the strong position of the burgesses, indeed following the raid the town was effectively placed under martial law to prevent looting and anticipate further attacks.

It was though surely in the interests of the burgesses to invest in the defence of Southampton. After all, their livelihoods depended upon the ability of goods to flow through the port. It is here that the burgesses are revealed as displaying a particularly self-destructive form of self-interest. They were reluctant to defend the waterfront as it would hinder trade and lower the value of their properties. ${ }^{59}$ Their concern was with the persistence of the everyday rhythms of port life, the ability to move goods to and from the quayside, to continue to trade in an efficient manner. They anticipated that a defensive scheme would impact upon their ability to do this, and, rather than adapting, they resisted the fortification of the waterfront in stone, even, it would seem, after defensive frailties had been highlighted in 1321.

Tension over the defences continued into the fifteenth century. Little care was taken by the burgesses in routinely maintaining the wall. In places, it was too thin to be fit for purpose, either to withstand bombardment or to offer a platform from which to defend the town. ${ }^{60}$ Periodically this vulnerability would be highlighted by royal surveys and measures taken to attempt to strengthen the defences, which were followed through to varying levels of effect.

We can see here how, depending upon the social relations in which people were enrolled, the wall and quayside afforded different things, ${ }^{61}$ and brought about different forms of vulnerability. For the crown, with its knowledge of the political

58 Platt (note 22), pp. 107-108.

59 Ibid., pp. 108-109.

60 Platt / Coleman-Smith (note 26), pp. 146-149.

61 Affordance is taken here to be a recognized capacity of a thing, emerging through knowledgeable interaction; see Carl KNAPPETT, Thinking Through Material Culture, Philadelphia 2005, pp. 45-47. 
situation and understanding of warfare the quay was periodically a point of vulnerability, for the merchants it was a place central to their lifestyle and the defences literally introduced a barrier to them trading in the most efficient manner. Furthermore, the periodic nature of the threat meant that vulnerability was not uniformly recognized, but acted upon episodically, allowing the defences to degrade, whether through the failure to maintain the stonework or the filling of ditches with domestic waste, with resilience having to be enacted as a process every time a threat was identified.

The example of the wall demonstrates how resilience building can introduce conflict. The aim is not to directly protect the physical structure of the town, but the social relations which flow through it and which it affords. ${ }^{62}$ Competing interests value these relations in different ways, and seek to protect them by identifying where they were vulnerable. Therefore, the overall resilience of the town itself came to be limited by the interests of certain groups and fluctuates with the power that these various groups are able to develop and exert. Royal action introduced vulnerability to the functioning of the port and the wealth of the merchants, whilst the political situation made the port vulnerable, but in a way, which could easily be written off as paranoia. Whilst this example is specific, it is a characteristic of resilience strategies that there is a trade-off and it is the values of a dominant group which are best catered for. The negligence displayed in relation to the defence of Southampton may have served the short-term interests of the mercantile burgesses, but placed the rest of Southampton's townspeople at risk. Political action may highlight or strengthen inequalities, and even limit the potential for recovery. ${ }^{63}$ In this tension we can reveal uneven power dynamics within the town, which arise from the historical freedoms and authority given to the burgesses by the crown.

The French raid had an uneven impact; houses around the waterfront, largely occupied by merchants, suffered the most extreme damage, whilst households in the east of the town were less directly affected. They were, however, exposed to the economic downturn which warfare and disease had brought about and for which the raid was a catalyst at the local scale. However, whereas the merchant burgesses can be shown to have sought to stratify the town through regulation and undertook actions which homogenized the economy of Southampton, the eastern part of the town exhibits greater diversity. Plots had substantial gardens and households were engaged in various craft activities. Whilst they may have provided labour around the quayside, their livelihood was more diverse than that of the mercantile households. These households appear as a heterogeneous element within the townscape, and may have been able to adapt, directing their efforts towards subsistence and continuing to produce goods for the local market which persisted despite a

62 GROVE (note 21), pp. 243-244.

63 Fox Gotham / Campanella (note 2), pp. 16-17. 
downturn in international trade. Pottery, of a type which appears to have emerged as a short-term replacement for types no longer available, was produced here as well. ${ }^{64}$ Although the burgesses utilized bureaucracy to seek to bring a specific form of urban order about, and were able to resist external power, we can see that meshwork elements persisted within the town. Whereas the merchants had to invest significant capital in rebuilding their homes and the quay facilities, and expend political capital in bringing Italian trade back to the port, within these meshwork elements life adapted more easily thanks to its heterogeneity. We should not, however, make the mistake of writing off the positive impacts of stratification. ${ }^{65}$ Bureaucratic tools are tools for persistence, allowing governance and Southampton's port function to persist, although they might also reify inequality by seeking to maintain a socio-economic and political status quo in the town; a trait which is characteristic of the rigidly hierarchical nature of medieval society.

This example demonstrates the implications of competing political interests for anticipatory behaviour. We can see that the ability to build resilience is historically contingent, here underpinned by charters granting burgesses power which constrained that ability of the crown to protect its interests. We can see how the interests of those in power are served by decisions about resilience building at certain scales, but also that less hierarchical and more heterogeneous elements of urban communities may display greater adaptability. This is not to say that these elements were unable to build resilience, but the scale at which they could act upon potential vulnerability was determined through historical processes. Whilst steps to build resilience opened or closed potential trajectories of unfolding, the adaptability of these marginalized elements of the urban community allowed them to act on this emerging future, by participating in urban processes, such as manufacture for the local market. Decision making, political interest and the form of urban assemblages therefore combine in messy ways to determine the ways in which the town unfolds, with resilience (or attempts at building resilience) having effects which are implicated in the future emergence of the town. This is a critical observation, as power over the future is not something in the hands of an identifiable urban elite, but emerges out of the ability of different sections of urban society to adapt and respond, creating possibilities for those who are marginal within formal power structures to play a role in shaping urban futures. It becomes clear that power is not imposed upon urban society, but rather, emerges in different forms out of particular everyday interactions, a phenomenon which is difficult to account for in generalising models of resilience which conceptualize power in more limited terms.

64 BROWN (note 22), pp. 18-19.

65 Delanda (note 34); Deleuze / GuatTari (note 34). 


\section{Southampton in the World}

An assemblage approach calls on us to consider the ways in which towns, as social processes, extend beyond their physical limits. The social relations which constitute Southampton are contingent both on performances of agricultural and commercial activity in its hinterland and on the performance of long-distance trade. Urban ecosystems are, therefore, more than the flora and fauna of the urban landscape, but extend into the agricultural hinterland. ${ }^{66}$ As ADGER demonstrates, resilience is dependent both on natural and political factors. ${ }^{67}$ Towns have implications for their hinterland. Towns which DELANDA might identify as 'hierarchical', 68 that is having a rigid structure, might be seen as exploiting a defined hinterland and, in turn, striating it through the management of the urban market. In contrast, gateway towns, such as ports, might draw on a wide hinterland. It is unclear how much direct influence Southampton had on its hinterland, but it had implications for decisions taken in the management of agricultural resources. Towns, or commerce in general, have the effect of limiting biodiversity and reducing the length of food chains, focussing on the conversion of biomass into energy for human consumption, be that in the form of grain or the conversion of plants into animal protein. ${ }^{69}$ Grain was imported to Southampton both from its hinterland and through its coastal contacts, with some being exported to the continent, particularly to provision troops in France. Here though, I wish to focus on another implication of the performance of Southampton, the performance of pastoral agriculture.

Although at the centre of our study, Southampton, and England in general, were at the periphery of an economic system which was focussed on the Italian economic powerhouses of Genoa and Venice. ${ }^{70}$ Trade with Genoese, Florentine and later Venetian merchants was critical to Southampton's development. ${ }^{71}$ Although they do not seem to have invested directly in pastoral husbandry, these merchants bought up stocks of wool to be processed into cloth in the Flemish cities in the thirteenth century and, later, exported cloth produced in Southampton's wider hinterland. Importantly, Southampton was not only a conduit for finished cloth, but also for dyestuffs imported by the Italians. ${ }^{72}$

66 DeLanda (note 34), p. 108.

67 ADGER (note 1), p. 354.

68 DeLanda (note 34).

69 Ibid., p. 108.

70 Janet ABu-Lughod, Before European Hegemony. The World System AD 1250-1350, Oxford 1989; Ben JERvis, Assembling the Archaeology of the Global Middle Ages, in: World Archaeology 49(5) (2017), pp. 666-680.

71 RudDOCK (note 25).

72 Hicks (note 31), pp. 156-157. 
By the fifteenth century, Southampton's trade was largely in the hands of foreign merchants, with Southampton's burgesses investing in shipping but largely providing hospitality and undertaking overland trade. ${ }^{73}$ Southampton therefore occupied a precarious position, reliant on the continuing interest of foreign merchants and the sustainable management of pastoral resources. The impact of sheep murrain on wool exports is well documented, and had implications for the prosperity of Flemish cloth producing centres. However, its impact on Southampton as a port is less clear, there was still a demand for wool and it commanded a high price, with it likely being the domestic rather than export market which lost out. ${ }^{74}$

By the fifteenth century, the principal wool producing landlord within Southampton's hinterland, the bishops of Winchester, had changed their agricultural strategy. Benefitting from a decline in population and adjusting to a rise in wages, sheep husbandry increased. A focus was placed on the processing of wool into cloth in the towns on the Winchester estate, with this finished product being exported through Southampton. Similar developments occurred across southern England. ${ }^{75}$ The typical narrative is one of simple economics, pasture became more profitable than arable stimulating a change. Whilst there is undoubtedly truth to this, we can also view this shift in terms of resilience. The placement of embargos on trade with Flanders, as well as sheep murrain, had revealed vulnerabilities in the supply chain. By taking charge of cloth production and increasing the size of flocks, landowners could build resilience by stockpiling wool, whilst also leasing pasture to farmers who could take on some of the risk of sheep husbandry.

These measures had implications for Southampton, over which its burgesses had little, if any, control. Resource management decisions were intended to address perceived vulnerability, seeking to secure a supply of wool and a maximisation of profit through the trade in cloth. Critically, these management decisions did not simply arise from local processes, they were stimulated by the spread of infestation, firstly of animals and later of people, and a demand for cloth which derived from eastern markets via Italian merchants. Here then we can see that attempts at building resilience outside of the core of the town still had implications for it, with pastoral husbandry, although a rural activity, becoming an element of an urban ecosystem, focussed not on Southampton but the Italian cities.

Here we can see Southampton as a gateway town, demonstrating meshwork characteristics. Rather than burgesses homogenising the hinterland to build resilience, we see this process arising from land management by the Bishop and his staff. Rather, Southampton's merchants adapted, they invested in quay facilities, provided hospitality and built links with foreign merchants. By being implicated in

73 Platt (note 22), pp. 152-153.

74 Ibid., pp. 154-155.

75 John Hare, The Bishop and the Prior. Demesne Agriculture in Medieval Hampshire, in: The Agricultural History Review 54(2) (2006), pp. 187-212. 
this trade, the leading burgesses' interests were aligned with these powers, meaning there was little short-term gain to be had in heterogenising the socio-spatial processes of the town. Here we can see Southampton as marginal and vulnerable. Whilst its interests were aligned with those of its trading partners it persisted as a port, with resilience coming from decisions taken outside, but with implications for, the urban population. The burgesses didn't control trade, but exhibit adaptability as they developed their capacity to provide hospitality and facilitate trade, as well as building partnerships through overland trade. However, the subsequent decline of Southampton in the sixteenth century clearly demonstrates the vulnerability introduced by this lack of control and short-term approach to economic growth. ${ }^{76}$

This example demonstrates how the fortunes of towns do not lie only in the decisions taken by their residents. By exploring the ways in which towns play a part in wider networks it is possible to examine how they were impacted by decisions taken outside, as land owners and powerful Italian merchants identified vulnerabilities and made changes to the supply chain to build resilience. This created spaces in which Southampton could display meshwork characteristics, but in which it was homogenized by external forces, making its existence, or at least its position in the urban hierarchy, precarious. ${ }^{77}$ One only has to think of the decline of cities focussed on single industries, such as Detroit, to understand how this resonates in contemporary society. But, despite sixteenth-century decline, port operations in Southampton persisted, albeit at a lower intensity. Infrastructure, networks and knowledge were not lost, but the port community adapted to prevailing conditions. The ability to build on experience and networks emphasizes the importance of everyday performance and the emergence of alternative forms of power, derived from these 'bottomup' interactions. Indeed, whilst the picture in twenty-first-century Detroit is often portrayed as bleak, some analysis shows that the persistence of knowledge and networks creates opportunities for innovation and adaptation. ${ }^{78}$ By exploring how communities like that of Southampton were able to adapt and persist over the long term, particularly through processes which exist outside of the hierarchical structures of power, contemporary cities can be more confident in their ability to recover, not through repetition but through adaptation, through a concern not with forcing hegemonic structure to persist, but instead allowing urban processes to emerge and adapt, to create spaces for innovation, recovery and alternative forms of power.

76 Platt (note 22) p. 223.

77 ZEBRowsKI (note 4), p. 168.

78 Robert MAXWELL, After the Car. Navigating the Archaeology of Abandonment in Detroit, Michigan, in: Post-Medieval Archaeology 46(2) (2012), pp. 347-352; Thomas J. Hannigan / Marcello Cano-Kollmann / Ram Mudambi, Thriving Innovation Amidst Manufacturing Decline. The Detroit Auto Cluster and the Resilience of Local Knowledge Production, in: Industrial and Corporate Change 24(3) (2015), pp. 613-634. 


\section{Conclusion}

By seeking to explore how the community of medieval Southampton acted in anticipatory ways, the archaeological and historical evidence reveals the inherent link between resilience, power and agency and demonstrates the value of an approach which is contextual, rather than reliant on a generalising model. Rather, if we are to generalize, an approach based on the mapping of social relations, may prove fruitful for understanding the character and emergence of resilience. This corresponds with developments in contemporary political analysis, geography and economics which have considered that resilience is an articulation of adaptability, which arises from social relations and can be characterized as a means of anticipating the future. The historical practices revealed show that power is emergent from sets of relations between people and the World, and that adaptation and resilience can, therefore, emerge at multiple scales and in ways which need not directly reflect the formal power dynamic within a town. My core point is to show that resilience is not a simple process, but is enacted simultaneously by different groups at various scales, potentially with conflicting imperatives. Approaches inspired by assemblage theory and related frameworks are increasingly common in archaeological theory and the social sciences, but we must be careful to understand the implications of assemblage thought, arising from its origins in radical politics as a means of creating the potential for transformation, both in contemporary society and in our understanding of the past not as awaiting discovery but as an ongoing, emergent process in the present; its goal not being to create a theory compatible with our knowledge of the past but to produce new knowledge which makes us alive to the possibilities of the past and of the future. ${ }^{79}$

A focus on resilience building allows us to think about how power emerges and is enacted over an emergent future, and provides potential both for understanding how past societies worked on potential futures, and how we may shape our own futures through a stronger awareness of the nature of power and its relationship to anticipatory action and adaptive capacity. The form that this power takes, whether it is over people, vibrant materials or agricultural resources, may vary, but wherever vulnerability is acted upon, the process of resilience building will have wider implications; potentially serving to marginalize the interests of other groups, or directing the ways in which they might be able to adapt. It is critical that we are alive to these implications, so as to better equip contemporary society to deal with challenges, particularly by exploring the potential to enfranchise those who are marginalized by over-arching power structures and facilitating, rather than restricting, their agency in shaping the future. Such reflection on the role of resilience building

79 Bertie Russell / Andre Pusey / Paul Chatterton, What Can an Assemblage Do? Seven Propositions for a More Strategic and Politicized Assemblage Thinking, in: City 15(5) (2011), pp. 577-583. 
in contemporary politics and the implications that power dynamics might have beyond their intended consequences, will better equip us to develop theoretical tools which allow us to traverse the constructed distinction between past and present, to work on both, not to reproduce power dynamics but to reveal and transform them in ways which allow agency to be re-distributed in productive ways to build more nuanced pasts and which enfranchise communities in anticipating their future. ${ }^{80}$

80 GRove (note 21), p. 246. 